\title{
Changes in Lead and Mercury Atmospheric Deposition Due to Industrial Emissions in Southeastern Brazil
}

\author{
L. D. Lacerda ${ }^{*, a, b}$ and M. G. Ribeiro ${ }^{b}$ \\ ${ }^{a}$ Instituto de Ciências do Mar, Universidade Federal do Ceará, Av. Abolição 3207, 60165-081 Fortaleza - CE, Brazil \\ ${ }^{b}$ Departamento de Geoquímica, Universidade Federal Fluminense, 24020-007 Niteroi - RJ, Brazil
}

Este estudo apresenta uma primeira estimativa de emissões de $\mathrm{Pb}$ e $\mathrm{Hg}$ para a Região Sudeste do Brasil, a região mais industrializada da América do Sul, durante o século XX, baseada na análise de perfis de sedimentos datados, coletados em lago ombrotrófico da Serra do Itatiaia, na região do vale do Rio Paraíba do Sul, Estado do Rio de Janeiro. As concentrações médias de $\mathrm{Pb}$ ao longo dos perfis variaram de $40 \mathrm{a} 180 \mu \mathrm{g} \mathrm{g}^{-1}$, enquanto que para $\mathrm{Hg}$ as concentrações variaram de $30 \mathrm{a} 420 \mathrm{ng} \mathrm{g}^{-1}$. As concentrações de $\mathrm{Hg}$ se correlacionaram significativamente com as de $\mathrm{Pb}$ até os anos 80 . A taxa de acumulação de $\mathrm{Pb}$ no período pré-industrial foi de cerca de $8,0 \pm 2,0 \mathrm{mg} \mathrm{m}^{-2}$ ano $^{-1}$, com um máximo observado na superfície dos perfis variando de 40 a $80 \mathrm{mg} \mathrm{m}^{-2}$ ano $^{-1}$. Por outro lado, a taxa de acumulação de $\mathrm{Hg}$ foi de $36 \pm 4 \mu \mathrm{g} \mathrm{m}^{-2}$ ano $^{-1}$, entre 1910 e 1940 , apresentando um máximo nos anos 60 de cerca de $120 \mu \mathrm{g} \mathrm{m}^{-2}$ ano $^{-1}$, e decrescendo novamente após os anos 70 para $20 \mu \mathrm{g} \mathrm{m}^{-2} \mathrm{ano}^{-1}$. O padrão de distribuição temporal da acumulação de $\mathrm{Hg}$ é similar aqueles relatados para diferentes regiões do hemisfério norte. Entretanto, as taxas de acumulação pré-industrial de $\mathrm{Pb}$ e $\mathrm{Hg}$ são de 3 a 6 vezes maiores que os valores relatados para o período pré-industrial no hemisfério norte. Emissões originadas na industrialização mais antiga no hemisfério norte podem ter influenciado a magnitude da acumulação pré-industrial na região em estudo, que se iniciou pelo menos 100 anos depois. No caso do $\mathrm{Hg}$, a mineração de ouro e prata nos três séculos anteriores, pode também ter influenciado as taxas de acumulação pré-industrial estimadas neste estudo.

This study presents the first estimate of $\mathrm{Pb}$ and $\mathrm{Hg}$ loads to southeastern Brazil, the most industrialized region of South America, during the $20^{\text {th }}$ century. This estimate was based on the analysis of dated ombrotrophic lake sediment cores, from the Itatiaia Mountains, at the Paraíba do Sul River valley region, in the Rio de Janeiro State. Average $\mathrm{Pb}$ concentrations along the cores ranged from 40 to $180 \mu \mathrm{g} \mathrm{g}^{-1}$, whereas for $\mathrm{Hg}$, concentrations ranged from 30 to $420 \mathrm{ng} \mathrm{g}^{-1}$. Mercury concentrations correlated significantly with $\mathrm{Pb}$ concentrations up to the middle of the 1980 's. Average regional pre-industrial (prior to 1940) $\mathrm{Pb}$ accumulation rate was $8.0 \pm 2.0 \mathrm{mg} \mathrm{m}^{-2} \mathrm{yr}^{-1}$, with maximum at the surface of the cores ranging from 40 to $80 \mathrm{mg} \mathrm{m}^{-2} \mathrm{yr}^{-1}$. The average $\mathrm{Hg}$ deposition rate was $36 \mu \mathrm{g} \mathrm{m}^{-2} \mathrm{yr}^{-1}$, between 1910 and 1940. A maximum of $120 \mu \mathrm{g} \mathrm{m}^{-2} \mathrm{yr}^{-1}$ was observed in the 1960's, with a further decrease after the late 1970's. The temporal $\mathrm{Hg}$ distribution pattern is similar to those reported in different regions of the northern hemisphere. However, regional pre-industrial $\mathrm{Pb}$ and $\mathrm{Hg}$ accumulation were from 3 to 6 times higher than those reported for the northern hemisphere. Emissions from the earlier industrialization of the northern hemisphere may have influenced the magnitude of regional pre-industrial $\mathrm{Pb}$ and $\mathrm{Hg}$ deposition in South America, where the industrialization started about 100 years latter. In the case of $\mathrm{Hg}$, gold and silver mining during the previous three centuries, may have also affected regional pre-industrial values.

Keywords: mercury, lead, atmospheric deposition, ombrotrophic lakes, South America

\section{Introduction}

Assessments of trace metals inputs to remote environments allow the characterization of their environmental impacts at the regional level. These

* e-mail: 1drude@ fortalnet.com.br measurements have shown an increase in trace metals concentrations relatively to the background values in many parts of the world. ${ }^{1}$ Surveys on trace metal concentrations in sediment cores have shown significant increases in the accumulation rates during the past 60 to 80 years. Debate still exists on the relative importance of the contribution of natural sources. ${ }^{2}$ However, most authors agree with the 
anthropogenic origin as the main cause for the increase of trace metals deposition in remote areas, what is best demonstrated where independent information about inputs is available.

Mercury and lead are typical global scale contaminants, due to the dominance of the atmospheric transport, and the relatively long residence time of these elements in the atmosphere. ${ }^{1}$ Estimates of the anthropogenic deposition of $\mathrm{Pb}$ and $\mathrm{Hg}$ in North America and Europe, showed increasing deposition rates during the $20^{\text {th }}$ century. Maximum deposition occurred in the 1960's and 1970 's, followed by a relative decrease, certainly due to emission control policies implemented in most industrialized nations in the last two decades. It was of particular importance the banning of $\mathrm{Pb}$ use in gasoline and the closing of chlor-akali plants using $\mathrm{Hg}$ cells in the production process. ${ }^{3-5}$

In general, pre-industrial (prior to 1850$) \mathrm{Pb}$ and $\mathrm{Hg}$ atmospheric deposition in remote areas of the northern hemisphere range from 1 to $8 \mathrm{mg} \mathrm{m}^{-2} \mathrm{yr}^{-1}$ and from 5 to $10 \mu \mathrm{g} \mathrm{m}^{-2} \mathrm{yr}^{-1}$, for $\mathrm{Pb}$ and $\mathrm{Hg}$ respectively. Maximum deposition occurred during the mid-seventies, reaching about 50 to $70 \mathrm{mg} \mathrm{m}^{-2} \mathrm{yr}^{-1}$ and up to $100 \mu \mathrm{g} \mathrm{m}^{-2} \mathrm{yr}^{-1}$, for $\mathrm{Pb}$ and $\mathrm{Hg}$ respectively. ${ }^{3,6,7}$ Present day rates estimated for those areas, however, are much lower ca. $4 \mathrm{mg} \mathrm{m}^{-2} \mathrm{yr}^{-1}$ for $\mathrm{Pb}$ and ranging from 10 to $25 \mu \mathrm{g} \mathrm{m}^{-2} \mathrm{yr}^{-1}$ for $\mathrm{Hg}^{5,6,8,9} \mathrm{Up}$ to now, however, only few consistent data are available for South America, notwithstanding its significant anthropogenic contribution of trace metals release to the atmosphere, in particular from Brazil, the largest and most industrialized country of this sub-continent. ${ }^{10,11}$ Few studies performed in the Brazilian Amazon, however, suggest that, at least for $\mathrm{Hg}$, regional deposition rates are linked not only to regional, but also to global anthropogenic emissions. ${ }^{12}$

In Brazil, studies on local $\mathrm{Pb}$ emissions are available, but restricted to the southeastern coastal region ${ }^{13}$ or to a single emission source, in particular related to energy generation. ${ }^{11,14}$ These isolated data are not sufficient for interpreting changes in the regional deposition rates observed in remote sites. Studies on $\mathrm{Pb}$ accumulation rates are only available for areas receiving inputs from river, such as bays and lagoons and are not comparable to ombrotrophic water bodies.

Emissions of $\mathrm{Hg}$ in Brazil are better studied and consistent data exist at the regional scale. As for $\mathrm{Pb}$, they are due to the accelerated industrialization of the country after World War II, particularly in the southeastern region. More recently, large amounts of $\mathrm{Hg}$ were emitted in the Amazon region due to gold mining, but most atmospheric deposition from this source is believed to occur in the Amazon region itself. ${ }^{15,16}$ Monitoring data from local environmental agencies and some few academic studies, have detected a decrease in $\mathrm{Hg}$ concentrations in fish and estuarine sediments in some highly polluted areas in the southeast. This decrease is generally believed to reflect the implementation of recent emission control polices, ${ }^{16,17}$ although, bulk atmospheric deposition data from industrialized areas still show relatively large numbers ( $c a$. $\left.76 \mu \mathrm{g} \mathrm{m}^{-2} \mathrm{yr}^{-1}\right) .^{18}$

Available estimates industrial annual emissions of $\mathrm{Hg}$ in Central and South America was first published by Pirrone et $a l .{ }^{10}$ and reach 73 tons, but this is most probably an underestimation. Brazil imports all its $\mathrm{Hg}$ from other countries, and the origin and fate of imported $\mathrm{Hg}$ have to be declared to the Brazilian authorities. Therefore, very accurate information exists for $\mathrm{Hg}$ industrial uses in Brazil, $^{19}$ and this information contradicts the suggested ${ }^{10}$ emissions. Industrial annual consumption of $\mathrm{Hg}$ in Brazil presented a maximum of $147 \mathrm{t}$ in 1980 , ranging from 110 to $147 \mathrm{t} \mathrm{y}^{-1}$ during the 1970 's. ${ }^{19,20}$ From 1980 onward, a decrease in industrial uses of $\mathrm{Hg}$ was observed in Brazil, which dropped to an annual average consume of about 70 t by $1989 .{ }^{19,20}$ Nearly $80 \%$ of this amount is used in the southeast. This consume of $\mathrm{Hg}$ in Brazil resulted in annual industrial emissions to the atmosphere, estimated by emission factor statistics, of about $38 \mathrm{t}$, approximately $89 \%$ of them emitted in the southeastern region. Today, annual emissions from the Brazilian industrial park is even smaller ${ }^{11}$ ranging from 16 to $25 \mathrm{t} \mathrm{yr}^{-1}$.

Gold mining is the major source of $\mathrm{Hg}$ to the atmosphere in Brazil. During its peak in the late 1980's, this activity contributed with about $110 \mathrm{t} \mathrm{yr}^{-1}$, nearly $65 \%$ of it to the atmosphere. ${ }^{15,20,21}$ Today, gold mining is much reduced due to the exhaustion of easily mined deposits, but still contributes with about $31 \mathrm{t} \mathrm{yr}^{-1}$, about $20 \mathrm{t} \mathrm{yr}^{-1}$ to the atmosphere. ${ }^{22}$ However, the few data on $\mathrm{Hg}$ atmospheric deposition due to gold mining have been estimated for the Amazon only, where this activity is largely concentrated. ${ }^{15,23,24}$

The present study estimates the $\mathrm{Pb}$ and $\mathrm{Hg}$ atmospheric deposition rates in Southeastern Brazil based on the accumulation rates determined in dated sediment cores, collected in high altitude ombrotrophic lakes located at the Paraíba do Sul River valley, the most industrialized areas in Brazil.

\section{Material and Methods}

Study site

The Itatiaia National Park is located at the Serra da Mantiqueira, along the Paraíba do Sul River valley, 
between the São Paulo and Rio de Janeiro cities (Figure 1). Most of the area is occupied by the Atlantic tropical rain forest formation, a high-density forest dominating altitudes up to $1,500 \mathrm{~m}$. Intermediate altitudes from 1,500 to $2,100 \mathrm{~m}$ are dominated by clouded evergreen forest, substituted by highland prairies up to $2,800 \mathrm{~m}$. In these prairies, ombrotrophic lakes are common. Rainfall in the area is over 2,300 $\mathrm{mm}$ per year, which keeps lakes permanently flooded. An alkaline rock complex dominates the geology of the region with alkaline granites covered by latossols, cambisols and litolic soils, at higher altitudes. This geology is particularly poor in heavy metals and no occurrence of $\mathrm{Pb}$ - or $\mathrm{Hg}$-bearing rocks is known for the entire region. Thus $\mathrm{Pb}$ and $\mathrm{Hg}$ reaching the lakes are mostly from atmospheric origin.

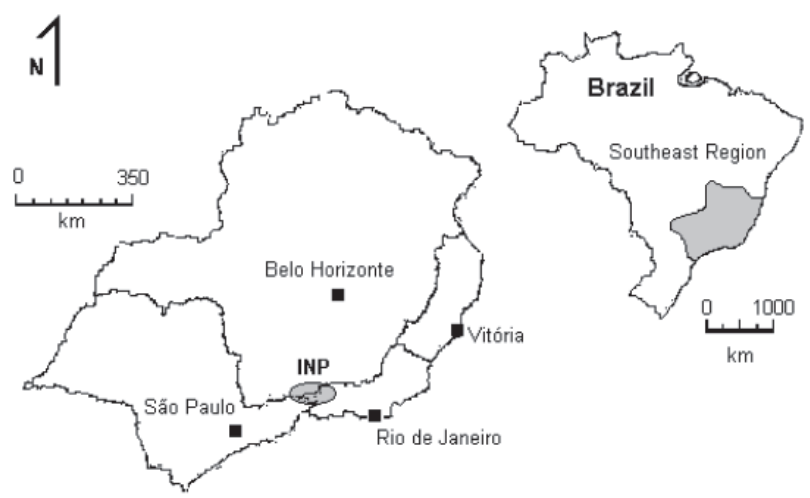

Figure 1. Study site: The Itatiaia National Park (INP), Southeastern Brazil.

\section{Sampling and analysis}

Samples were collected in one of the most remote and permanently flooded lakes of the highland prairies, located at approximately $2,460 \mathrm{~m}$ of altitude $\left(22^{\circ} 22^{\prime} 24^{\prime \prime} \mathrm{S} ; 44^{\circ}\right.$ 42 ' 10 ' W), in accordance to accepted protocols. ${ }^{25}$ In this lake, two cores were manually collected, inserting acrylic tubes into the sediment to a depth of $50 \mathrm{~cm}$. The first 23 $\mathrm{cm}$ were sliced in $1.0 \mathrm{~cm}$ layers and in $5.0 \mathrm{~cm}$ layers from this depth onward. Samples were stored in acid-clean plastic bags and frozen for transport.

In laboratory, the sediment samples were oven-dried at $50{ }^{\circ} \mathrm{C}$ to constant weight (approximately $24 \mathrm{~h}$ ). Approximately $1.0 \mathrm{~g}$ of the dried sample was digested in a closed system at $60-70{ }^{\circ} \mathrm{C}$ for 1.0 hour with $20 \mathrm{~mL}$ of $50 \% \mathrm{v} / \mathrm{v}$. aqua regia solution $\left(4 \mathrm{~mL} \mathrm{HCl}+6 \mathrm{~mL} \mathrm{HNO}_{3}+10 \mathrm{~mL} \mathrm{H}_{2} \mathrm{O}\right)$ in duplicate. ${ }^{26}$ The resulting extracts were centrifuged during $15 \mathrm{~min}$ at approximately 2,000 rpm. Mercury was determined by Cold Vapor Atomic Absorption Spectrophometry (CVAAS), in a Bacharat Model spectrophotometer. The detection limit, based on 3 times the standard deviation of the response of the reagent blank, was $6 \mathrm{ng} \mathrm{g}^{-1}$. Simultaneously, the same analytical procedure was used to determine $\mathrm{Hg}$ in a certified reference material standard (NIST-USA, Buffalo River Sediment, with a certified value of $\left.60 \mathrm{ng} \mathrm{g}^{-1}\right)$. The found results of $58 \pm 6 \mathrm{ng} \mathrm{g}^{-1}, \mathrm{n}=15$, were in good concordance with the certified one.

Additionally, in one core, the organic matter content was determined in duplicate in the $1.0 \mathrm{~g}$ dried samples, after heating at $450{ }^{\circ} \mathrm{C}$ for $24 \mathrm{~h}$. The ashes were dissolved with a strong acid mixture $\left(2 \mathrm{~mL} \mathrm{HNO}_{3}+3 \mathrm{~mL} \mathrm{HCl}+1 \mathrm{~mL}\right.$ $\mathrm{HF}$ ) at $60-70^{\circ} \mathrm{C}$ for $2 \mathrm{~h}$, in duplicate, for the determination of the total $\mathrm{Fe}$ and $\mathrm{Pb}$ contents by conventional flame atomic absorption spectrophotometry. ${ }^{27}$ Simultaneously, the same analytical procedure was used to determine $\mathrm{Fe}$ and $\mathrm{Pb}$ in a certified reference material standard (NISTUSA, SRM 1646a - Estuarine Sediment). The found results showed recuperation of $105 \%$ for $\mathrm{Fe}$ and 95 for $\mathrm{Pb}$, therefore in good concordance with the certified values.

Sub-samples from the two cores used for $\mathrm{Hg}$ determinations were dated by the analysis of the excess of ${ }^{210} \mathrm{~Pb}$, at the Laboratory of Geochemistry from the University of Nice, France. Excess ${ }^{210} \mathrm{~Pb}$ distribution in the cores were fairly consistent and gave an estimated sedimentation rate of $0.45 \mathrm{~cm} \mathrm{yr}^{-1}$, constant for at least the past 60 to 80 years. Details on dating methodology and statistics, and on ${ }^{210} \mathrm{~Pb}$ activity and temporal distribution in the cores, are published elsewhere. $^{28}$

\section{Results and Discussion}

\section{Concentrations distribution}

The $\mathrm{Pb}$ concentrations were also used as tracers of major industrial inputs ${ }^{29}$ to help interpret the $\mathrm{Hg}$ distribution, whereas the organic matter and Fe distribution was used to detect eventual post-deposition mobilization in the core, since water table fluctuations, which may result in redistribution of deposited $\mathrm{Pb}$ and $\mathrm{Hg}$, would result in changes in the Fe redox state and organic matter oxidation. ${ }^{30}$

Organic matter and $\mathrm{Fe}$ distribution in core from Itatiaia, are presented in Figures 2A, B. Organic matter content is constant along the core and ranged less than 5\%, from 92 to $97 \%$, except in the first top slice where it drops to approximately $70 \%$, probably due to more intense oxidation at the sediment-water interface. Concentrations of Fe were lowest $(\sim 0.06 \%)$ and nearly constant below $24 \mathrm{~cm}$. From $24 \mathrm{~cm}, \mathrm{Fe}$ concentrations increased to a maximum at $19 \mathrm{~cm}(1.8 \%)$, decreasing again to about $0.5 \%$ at $18 \mathrm{~cm}$ and increasing steadily from that depth to the top of the core, with peak concentrations in the first $1 \mathrm{~cm}$ reaching $2.2 \%$. The largest peak between $18-20 \mathrm{~cm}$ of depth 

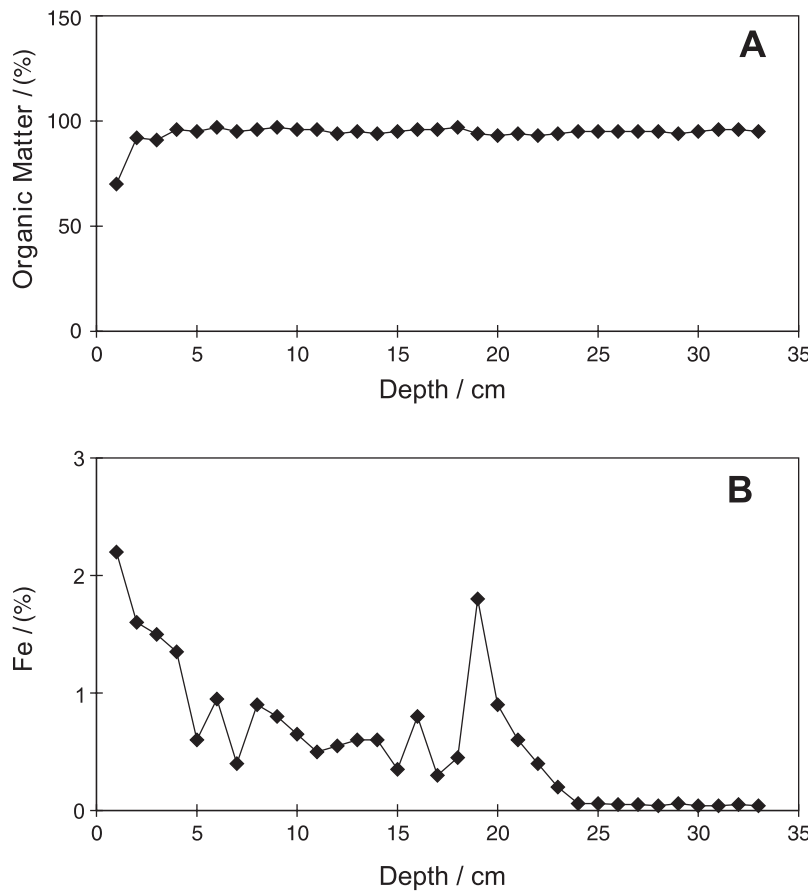

Figure 2. Distribution of organic matter (A) and Fe concentrations (B) in core Itatiaia II. Concentrations are on a dry weight basis.

corresponds approximately to the beginning of the industrialization of the Paraíba do Sul Valley (see Figure 4 for corresponding dating). The extremely constant values of organic matter content suggest that water table fluctuations, which may result in the redistribution of deposted metals, is of minor, if any, importance to this lake. Likewise, the steady increase in Fe concentrations from $18 \mathrm{~cm}$ upward does not suggest any significant redox changes along the core. The Fe distribution along the core is difficult to interpret, but is probably due to anthropogenic emissions, since $\mathrm{Fe}$ is a major component of the effluents of various industries of the Paraíba do Sul river valley, which include one of the largest steel plant and iron smelter of the country. More detailed coring, however, is needed to fully interpret Fe deposition in the Itatiaia Mountains. Notwithstanding, for the specific objectives of the present work, the results on the organic matter and $\mathrm{Fe}$ distribution in the sedimentary column, suggest that any variation in $\mathrm{Hg}$ and $\mathrm{Pb}$ concentrations along the profiles, is mostly due to changes in loading rates, rather than post-depositional mobilization.

Lead concentrations (Figure 3) followed the same general trend as that of $\mathrm{Fe}$, with lower concentrations of approximately $40 \mu \mathrm{g} \mathrm{g}^{-1}$, observed in the lower slices (up to $23 \mathrm{~cm}$ ) and an increase from this depth to the top, reaching $70 \mu \mathrm{g} \mathrm{g}^{-1}$ in sub-surface layers. A larger peak $\left(180 \mu \mathrm{g} \mathrm{g}^{-1}\right)$ was observed in the first $\mathrm{cm}$, also found for the ${ }^{210} \mathrm{~Pb}$ data $\left(\right.$ not $\operatorname{shown}^{30}$ ). This may be due to the

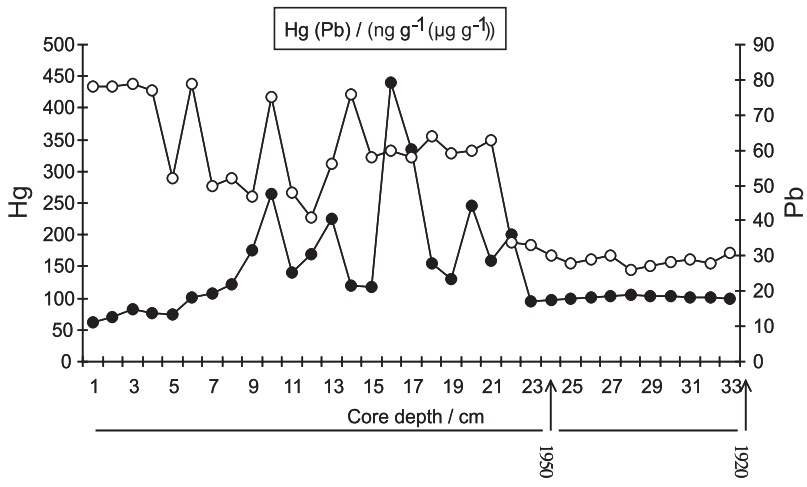

Figure 3. Distribution of $\mathrm{Pb}$ (open circles) and $\mathrm{Hg}$ (dark circles) average concentrations of Itatiaia I and II cores.

remobilization and oxidation at the sediment-water interface. This is also suggested by the drop in the organic matter content at the surface layer of the core. But since they only affect the first $1 \mathrm{~cm}$ layer, such processes have no importance in deeper layers.

Lead and $\mathrm{Fe}$ concentrations presented a significant positive correlation $(\mathrm{r}=0.714 ; \mathrm{P}<0.01)$ but no significant correlation with the organic matter content. The lack of correlation with the organic matter content and the concentration increase of both metals from the 1940's (on Figure 4), suggest the industrialization of the Paraíba do Sul River valley as the major source of these two elements to the lake. In the case of $\mathrm{Pb}$, another significant source is the use of gasoline as fuel, which was leaded up to 1986. The economic growth in the last 10 years of the $20^{\text {th }}$ century, in particular the steel industry, which production increased from 20.6 Mt in 1992 to $26.7 \mathrm{Mt}$ in 2000 (about 30\%), ${ }^{31}$ is probably responsible for the additional increase in the $\mathrm{Pb}$ and $\mathrm{Fe}$ concentrations in the first $5.0 \mathrm{~cm}$ of the core.

The variation of $\mathrm{Hg}$ concentrations is also presented in Figure 3. Average $\mathrm{Hg}$ concentrations ranged from 30 to $420 \mathrm{ng} \mathrm{g}^{-1}$. Similar to $\mathrm{Fe}$ and $\mathrm{Pb}, \mathrm{Hg}$ concentrations were lower and constant at deeper parts of the cores (up to $23 \mathrm{~cm}$ ) with the maximum concentration occurring in the $16-18 \mathrm{~cm}$ layer $\left(420 \mathrm{ng} \mathrm{g}^{-1}\right)$. However, contrary to the other

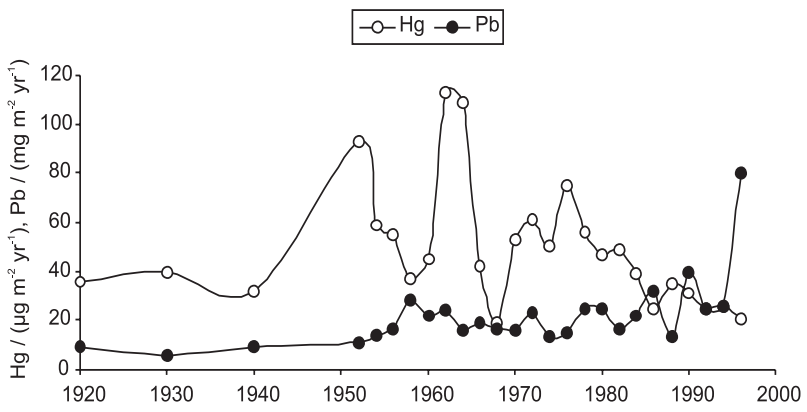

Figure 4. Average accumulation rates of $\mathrm{Pb}$ and $\mathrm{Hg}$ estimated from dated sediment cores from Itatiaia Mountains lake cores. 
two metals, $\mathrm{Hg}$ concentrations showed a decrease towards the top of the core, starting around $8 \mathrm{~cm}$, corresponding to the late 1980 's. Surface concentrations ranged from 20 to $40 \mathrm{ng} \mathrm{g}^{-1}$. No anomalous $\mathrm{Hg}$ concentration peak was detected at the first $1.0 \mathrm{~cm}$ layer of the cores, suggesting that whatever processes causing the surface concentration peak observed for $\mathrm{Fe}$ and, in particular for $\mathrm{Pb}$, do not affect the $\mathrm{Hg}$ distribution in the cores.

Decreasing $\mathrm{Hg}$ concentrations in surface layers of sediment cores has been frequently observed in lakes of the northern hemisphere, and at least in one study on the continental shelf sediments of the Rio de Janeiro coast. ${ }^{32}$ However, this decrease has not been observed in similar studies in Amazon gold mining areas of Brazil, which consistently show increasing $\mathrm{Hg}$ concentrations toward the top of lake sediment profiles. ${ }^{12,22,33,34}$ Surface $\mathrm{Hg}$ concentrations in the Itatiaia Mountains lake studied here are much lower than those measured in lake sediments in the Amazon. For example, in the Pantanal region, Central Brazil, ${ }^{22,34-36} \mathrm{Hg}$ concentrations in surface sediments of remote lakes range from 60 to $120 \mathrm{ng} \mathrm{g}^{-1}$. In the Carajás mountains, ${ }^{12,16}$ southeastern Amazon, ombrotrophic lakes, similar to those of the Itatiaia Mountains, present $\mathrm{Hg}$ concentrations in surface sediments ranging from 80 to $310 \mathrm{ng} \mathrm{g}^{-1}$, while at the Alta Floresta mining area, ${ }^{16,34}$ southern Amazon, concentrations ranged from 80 to 210 $\mathrm{ng} \mathrm{g}^{-1}$. These results are in accordance to previous estimates $^{15,16,19,21}$ suggesting the larger importance of Amazon $\mathrm{Hg}$ emissions relatively to industrial emission ${ }^{5}$ in Brazil, in the recent past.

\section{Accumulation rates}

Estimates of the $\mathrm{Hg}$ and $\mathrm{Pb}$ accumulation rates are presented in Figure 4. Since the studied lake is predominantly ombrotrophic, accumulation rates reflect principally the atmospheric deposition of the metals. As expected, $\mathrm{Pb}$ accumulation rates (Figure 4), increased from nearly constant values $\left(8.0 \pm 2.0 \mathrm{mg} \mathrm{m}^{-2} \mathrm{yr}^{-1}\right)$ from 1910 to 1940 , to approximately $20 \mathrm{mg} \mathrm{m}^{-2} \mathrm{yr}^{-1}$, between 1950 and 1980 , and increased to a maximum of about $40 \mathrm{mg} \mathrm{m}^{-2} \mathrm{yr}^{-1}$, at sub-surface layers. At the top $1.0 \mathrm{~cm}$, if the anomalous high concentration is considered, $\mathrm{Pb}$ accumulation rate would reach $80 \mathrm{mg} \mathrm{m}^{-2} \mathrm{yr}^{-1}$.

Notwithstanding the typical industrial emissioninfluenced profile of $\mathrm{Pb}$, we still consider this lake as remote, since accumulation rates of $\mathrm{Pb}$ are at least one order of magnitude lower than those reported for other industrialized regions. For example, a survey of several Canadian lakes ${ }^{29}$ showed $\mathrm{Pb}$ accumulation rates ranging from 400 to $950 \mathrm{mg} \mathrm{m}^{-2} \mathrm{yr}^{-1}$. Typical rates measured in south Sweden also reach much higher values $(2,000$ to $4,500 \mathrm{mg} \mathrm{m}^{-2} \mathrm{yr}^{-1}$ ), whereas remote lakes in the same country showed similar values to those reported here. ${ }^{37}$

Mercury accumulation rates (Figure 4) ranged from a relatively constant value from 1910 to $1940\left(36 \pm 4 \mu \mathrm{g} \mathrm{m}^{-2}\right.$ $\mathrm{yr}^{-1}$ ) increasing from 1940 onward, following the industrialization of the Paraíba do Sul River valley, and reached a maximum in the 1960 's, of approximately 120 $\mu \mathrm{g} \mathrm{m} \mathrm{m}^{-2} \mathrm{yr}^{-1}$. Contrary to $\mathrm{Pb}$ however, $\mathrm{Hg}$ accumulation decreased from the late 1970 's to the present, to values ranging from 15 to $30 \mu \mathrm{g} \mathrm{m}^{-2} \mathrm{yr}^{-1}$, at the top of the core. This decrease is probably resulting from emission control measures implemented by that time, in particular the banning of $\mathrm{Hg}$-containing agro-chemicals and changing chlor-alkali plants technology, which have significantly reduced $\mathrm{Hg}$ industrial emissions in Brazil ${ }^{17,20,21}$ and the $\mathrm{Hg}$ contamination of the aquatic environments of southeastern Brazil as well. ${ }^{19}$ The 5 to 6 times decrease in $\mathrm{Hg}$ accumulation rates observed in the Itatiaia lake cores, compares well with the estimated decrease in $\mathrm{Hg}$ industrial emissions from about $150 \mathrm{t}$ in 1979 , to approximately 30 $\mathrm{t}$ in 1995. ${ }^{15,20}$ This decrease also suggests that $\mathrm{Hg}$ emitted from gold mining areas in the Amazon has no influence on Southeastern Brazil and agrees with the regional differences between the $\mathrm{Hg}$ concentrations in surface sediments of aquatic environments in both areas. ${ }^{16}$

The temporal variation in $\mathrm{Hg}$ accumulation rates observed in the Itatiaia cores is similar to those reported for different regions of the northern hemisphere, which also reported peak values in the 1960 's and 1970 's. ${ }^{25,29}$ Also, peak accumulation in the Itatiaia lake compares well with those reported for remote lakes in the Midwest USA ${ }^{5,38}$ and with the average $\mathrm{Hg}$ accumulation rate estimated for the Great Lakes,${ }^{10}$ that is $135 \mu \mathrm{g} \mathrm{m}{ }^{-2} \mathrm{yr}^{-1}$. However, preindustrial $\mathrm{Hg}$ accumulation rates are from 3 to 6 times higher than those reported for remote areas in the northern hemisphere, ${ }^{5,37,39}$ which range from 5 to $10 \mu \mathrm{g} \mathrm{m}^{-2} \mathrm{yr}^{-1}$. Emissions from gold and silver mining during the previous three centuries, which amounted nearly 200,000 $t$ in Latin America ${ }^{40}$ with mean annual emissions of $316 \mathrm{t}$, may have influenced the magnitude of pre-industrial $\mathrm{Hg}$ accumulation observed in the Itatiaia Mountains. Preliminary evidence of the influence of the colonial mining on $\mathrm{Hg}$ deposition rates in South America has already been reported, at least for the Amazon region. ${ }^{12}$

Alternatively, $\mathrm{Hg}$ atmospheric deposition in many regions of the northern hemisphere started raising by 1850 and were relatively high form 1900 to $1940,,^{3,5,38}$ frequently reaching values higher than $30 \mu \mathrm{g} \mathrm{m}^{-2} \mathrm{y}^{-1}$ and even surpassing $100 \mu \mathrm{g} \mathrm{m}^{-2} \mathrm{y}^{-1}$ during the Second World War. ${ }^{41}$ Therefore, some $\mathrm{Hg}$ from the northern hemisphere 
industrial revolution may have eventually reached the southern hemisphere, similarly to the $\mathrm{Pb}$ occurrence in the Antarctic ice. ${ }^{42}$ Unfortunately, the scarce data on $\mathrm{Pb}$ (only one core) do not allow further discussion of its use as a tracer of industrial anthropogenic emissions prior to the $20^{\text {th }}$ century. Better coring is needed for further discussion of the pre-industrial $\mathrm{Hg}$ atmospheric deposition in the region, but trans-hemisphere transport of $\mathrm{Hg}$ and/or the influence of colonial gold and silver mining, cannot be ruled out.

Present day average $\mathrm{Hg}$ accumulation rates measured in the Itatiaia mountains $\left(15-30 \mu \mathrm{g} \mathrm{m}^{-2} \mathrm{y}^{-1}\right)$, however, are similar to recent average deposition rates reported for North America $^{3,5,8,25}$ and for northern Europe, ${ }^{4,29,38}$ which range from 9 to $30 \mu \mathrm{g} \mathrm{m}^{-2} \mathrm{yr}^{-1}$. Considering that the area is mostly affected by industrial emissions, these deposition rates are in agreement with emissions from industrial sources in southeastern Brazil. ${ }^{15}$ Notwithstanding, they are much lower than those measured in areas receiving direct atmospheric effluents from industrial sources in this region of Brazil ${ }^{18}$ which may reach up to $76 \mathrm{\mu gm}^{-2} \mathrm{yr}^{-1}$. Therefore, the accumulation rates estimated for the Itatiaia Mountains shall be viewed as a regional average for remote sites in southeast Brazil.

\section{Conclusions}

Mercury atmospheric deposition measured in the Itatiaia Mountains provides a figure for South America similar to that of North America and Europe, with values showing a significant decrease in response to specific emission control measures implemented in the last 20 years. Unfortunately however, these measures seem to be only effective for $\mathrm{Hg}$, since $\mathrm{Pb}$ accumulation, contrary to reports for the northern hemisphere, showed no similar decrease for the present day values. More data are needed to explain the relatively high pre-industrial $\mathrm{Hg}$ accumulation rates reported here. Both colonial silver and gold mining and the earlier industrial revolution in the north hemisphere may have influenced these values.

\section{Acknowledgments}

This study was supported by the Conselho Nacional de Desenvolvimento Científico e Tecnológico (CNPq), Brazil, as part of the PRONEX Program, 46.6090/2001-3 and Fundação de Amparo a Pesquisa do Estado do Rio de Janeiro (FAPERJ) as part of the PRONEX Program E-26/ $171.175 / 2003$. Dating of sediment cores was possible thanks to the CNPq-CNRS agreement between Brazil and France. The authors also thank Dr. W.Z. de Mello and M.Sc.
Carlos Novaes for their help during the sampling. The extensive reviews of two anonymous referees from the JBCS are mostly appreciated.

\section{References}

1. Nriagu, J.O.; Science 1996, 272, 223.

2. Rasmussem, P.E.; Environ. Geol. 1998, 33, 96.

3. Swain, E.B.; Engstrom, D.R.; Brigham, M.E.; Henning, T.A.; Brezonik, P.L.; Science 1992, 257, 784

4. Iverfeldt, A.; Munthe, J.; Brosset, C.; Pacyna, J.M.; Water Air Soil Pollut. 1995, 80, 227.

5. Pirrone, N.; Alegrini, I.; Keeler, G.J.; Nriagu, J.O.; Rossmann, R.; Robins, J.A.; Atmospheric Environ. 1998, 5, 929.

6. Vile, M.A.; Wieder, R.K.; Novak, M.; Environ. Sci. Technol. 2000, 34,12.

7. Sonke, J.E.; Burnett, W.C.; Hoogerff, J.A.; van der Laan, S.R., Vangrosveld, J.; Corbett, D.R.; J. Paleolimnol. 2003, 29, 95.

8. Mason, R.P.; Fitzgerald, W.F.; Morel, M.M.; Geochim. Cosmochim. Acta 1994, 58, 3191.

9. Chillrud, S.N.; Bopp, R.F.; Simpson, H.J.; shuster, E.L.; Chaky, D.A.; Walsh, D.C.; Choy, C.C.; Tolley, L.R.; Yarme, A.; Environ. Sci. Technol. 1999, 33, 657.

10. Pirrone, N.; Keeler, G.L.; Nriagu, J.O.; Atmos. Environ. 1996, 30,145 .

11. Vaisman, A.; Lacerda, L.D.; Reg. Environ. Change. 2003, 3, 140.

12. Lacerda, L.D.; Ribeiro, M.G.; Cordeiro, R.C.; Siffedine, A.; Turcq, B.; Cienc. Cult. J. Braz. Ass. Adv. Sci. 1999, 51, 363.

13. Lacerda, L.D.; Marins, R.V.; Barcellos, C.; LOICZ Res. Stud. 2002, 21, 99

14. Lacerda, L.D.; Guerra, T.; Castilhos, Z.C.; Hatje, V.; Canesin, F.P.; Cunha, L.C. In Proc. $10^{\text {th }}$ Inter. Conf. Heavy Metals Environment; Nriagu, J.; Allan, R.J., eds., CEP Consultants: Edinburgh, 1995, vol. 2, p. 81.

15. Lacerda, L.D.; Marins, R.V.; J. Geochem. Explor. 1997, 58, 223.

16. Lacerda, L.D.; Salomons, W.; Mercury from Gold and Silver Mining: A Chemical Time-Bomb?, Springer-Verlag: Berlin, 1998, p. 146.

17. Eysink; G.G.J. In Riscos e Consequências do Uso do Mercúrio, Hacon, S.; Lacerda, L.D.; Pfeiffer, W.C.; Carvalho, D., eds. FINEP/UFRJ: Rio de Janeiro, 1990, p. 12.

18. Marins, R.V.; Silva Filho, E.V.; Lacerda, L.D.; J. Braz. Chem. Soc. 1996, 9, 77.

19. Ferreira, R.H.; Appel, L.E.; In Proc. $1^{\text {st }}$ Inter. Symp. Environmental Studies of Tropical Rain Forests; Bruni, M., ed., Biosfera: Rio de Janeiro,1991, vol. 1, p. 207.

20. Lacerda, L.D.; Water Air Soil Pollut. 1997, 97, 247.

21. Moreira, J.C.; Piveta, F.; Water Air Soil Pollut. 1997, 97, 241

22. Lacerda, L.D.; Environ. Geol. 2003, 43, 308. 
23. Lacerda, L.D.; Salomons, W.; Pfeiffer, W.C.; Bastos, W.R.; Biogeochemistry 1991, 14, 71.

24. von Tümpling, W.; Wilken, R.D.; Einax, J.; J.Geochem. Explor. 1995, 52, 127.

25. Porcella, D.B.; Protocol for Estimating Historic Atmospheric Mercury Deposition, Technical Report - TR - 106768, Eletric Power Research Institute: Palo Alto, 1996, p. 46.

26. Marins, R.V.; Lacerda, L.D.; Paraquetti, H.H.M.; Paiva, E.C.; Villas-Boas, R.C.; Bull. Envioron. Cont. Toxicol. 1998, 61, 57.

27. Machado, W.; Silva Filho, E.V.; Oliveira, R.R.; Lacerda, L.D.; Mar. Pollut. Bull. 2002, 44, 1227.

28. Calvelli, S.; Datation des Sediments Lacustres Amazonienes par le Plomb 210 Correlation avec les Retombes de Mercure, Memoire de Matrise des Sciences de la Terre, Université de Nice: Nice, 1998, p. 32.

29. Blais, J.M.; Kalf, J.; Biogeochemistry 1993, 23, 1.

30. Meili M.; Water Air Soil Pollut. 1995, 80, 637.

31. Yamassaki, M.H.; Caldeira, L.M.; A Indústria Siderúrgica Brasileira após 10 Anos de Privatização: Uma Análise Financeira do Caso ACESITA. http://www.cepefin.com.br/ artigos/industriasiderurgicabrasileiraacesita.pdf, 2001, p. 10 . (accessed on 26 June 2004)

32. Lacerda, L.D.; Carvalho, C.E.V.; Rezende, C.E.; Pfeiffer, W.C.; Mar. Pollut. Bull. 1993, 26, 220.
33. Cordeiro, R.C.; Turcq, B.; Ribeiro, M.G.; Lacerda, L.D.; Capitâneo, J.; Oliveira da Silva, A.; Sifeddine, A.; Turcq, P.M.; Sci. Total Environ. 2002, 293, 247.

34. Godoy, J.M.; Padovani, C.R.; Guimarães, J.R.D.; Pereira, J.C.A.; Vieira, L.M.; Carvalho, Z.L.; Galdino, S.; J. Braz. Chem. Soc. 2002, 13, 71 .

35. Leady, B.S.; Gottgens, J.F.; Wetlands Ecol. Manag. 2001, 9, 349.

36. Guimarães, J.R.D.; Meili, M.; Malm, O.; Brito, E.M.S.; Sci. Total Environ. 1988, 213, 165.

37. Renberg, I.; Person, M.W.; Emteryd, O.; Nature 1994, 368, 323.

38. Engstrom, D.R.; Swain, E.B.; Environ. Sci. Technol. 1997, 31,960 .

39. Steines, E.; Andersson, E.M.; Water Air Soil Pollut. 1991, 56, 391.

40. Nriagu, J.O.; Sci. Total Environ. 1994, 149, 167.

41. Hylander, L.D.; Meili, M.; Sci. Total Environ. 2003, 304, 13.

42. Boutron, C.F.; Patterson, C.C.; Geochim. Cosmochim. Acta 1983, 47, 1355.

Received: September 8, 2003 Published on the web: November 18, 2004 